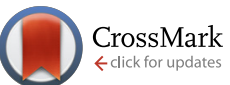

Cite this: Med. Chem. Commun., $2015,6,2158$

Received 4th August 2015

Accepted 20th September 2015

DOI: $10.1039 / c 5 m d 00320 b$

www.rsc.org/medchemcomm

\title{
Synthesis of indole-derived allocolchicine congeners exhibiting pronounced anti- proliferative and apoptosis-inducing properties $\uparrow$
}

\author{
Nikolay S. Sitnikov, ${ }^{\text {ab }}$ Alexander V. Sinzov, ${ }^{a}$ Diane Allegro, ${ }^{c}$ Pascale Barbier, ${ }^{c}$ \\ Sebastien Combes, ${ }^{d}$ Liliane Abodo Onambele, ${ }^{e}$ Aram Prokop, ${ }^{e}$ \\ Hans-Günther Schmalz ${ }^{b}$ and Alexey Yu. Fedorov*a
}

\begin{abstract}
Based on the natural antimitotic agent allocolchicine as a lead structure, a series of novel indole-based allocolchicine congeners was synthesized and assessed in vitro for their cytostatic properties. Several compounds exhibited potent anti-proliferative and apoptosis-inducing activity towards lymphoma cells along with low unspecific cytotoxicity. The observed activity is supposed to result from the inhibition of microtubule assembly, as indicated by the tubulin polymerisation assay.
\end{abstract}

\section{Introduction}

Colchicine (1), ${ }^{1,2}$ an alkaloid isolated from plants of the genera Colchiceae, Merendera and Gloriosa, is a long-known natural product exhibiting high levels of cytotoxicity towards proliferating cells. The origin of its biological effect lies in the ability to inhibit polymerisation of tubulin, the main constitutive protein of microtubules. ${ }^{3-7}$ This effect leads to the disruption of mitotic spindle formation, arrest of the cell cycle in G2/M phase and, eventually, apoptotic cell death. The intriguing biological properties of colchicine as well as its unique structural features ${ }^{8}$ became a motivation for a number of total syntheses (resulting in one of the most fascinating endeavours in the history of organic synthesis), ${ }^{8}$ as well as several studies concerning the structure-activity relationship (SAR) of colchicine structural analogs. ${ }^{3,9-11}$ While high systemic toxicity ${ }^{12,13}$ (resulting in strong gastrointestinal upset, neuropathy, and bone marrow suppression) has prevented its use in the treatment of cancer, colchicine (1) became a lead structure in the design of novel tubulin polymerisation inhibitors. Along with several classes of structurally related compounds (e.g. combretastatins ${ }^{14-17}$ and 4-arylcoumarins ${ }^{18}$ ), allocolchicine $(2)^{19}$ and its

\footnotetext{
${ }^{a}$ Department of Organic Chemistry, Lobachevsky State University of Nizhni Novgorod, Gagarina Av. 23, Nizhni Novgorod 603950, Russia. E-mail:afnn@rambler.ru

${ }^{b}$ Department für Chemie, Universität zu Köln, Greinstr. 4, 50939, Köln, Germany ${ }^{c}$ Aix-Marseille Université, INSERM, CRO2 UMR_S 911, F-13005, Marseille, France ${ }^{d}$ Laboratory of Integrative Structural and Chemical Biology, Institut PaoliCalmettes, Aix-Marseille Université, UM 105, F-13009, Marseille, France ${ }^{e}$ Department of Pediatric Hematology/Oncology, Children's Hospital Köln, Amsterdamer Str. 59, 50735 Köln, Germany

$\dagger$ Electronic supplementary information (ESI) available: Synthetic procedures and characterisation data for all new compounds; details of biological experiments. See DOI: 10.1039/c5md00320b
}

analogues $^{9-11,20-27}$ were identified as promising candidates for further development. Recently, our group reported the synthesis and biological evaluation of a series of heterocyclic allocolchicine congeners (for instance 3 and 4, Fig. 1), in which ring $\mathrm{C}$ of the parent compound 2 is replaced with an indole 28,29 or a benzofuran ${ }^{30}$ pharmacophore. Allocolchicinoids 3 and 4 showed high levels of proliferation inhibition and apoptosis induction at nanomolar concentrations against different lymphoma cells, although their unspecific cytotoxicity was found to be particularly low. ${ }^{28}$ Herein, we report the synthesis of pyrrolo-allocolchicinoids of type 5 , i.e. the constitutional isomers of 3 and 4 , and present the primary results of their biological assessment using a human lymphoma cell line. In addition, the influence of the compounds on tubulin polymerisation was determined in vitro.<smiles>CC[14c]1cc(OC)c(=O)cc2c1-c1c(cc(OC)c(OC)c1OC)[C@H](NC)CC2</smiles>

$(-)-(a R, 7 S)$ colchicine 1

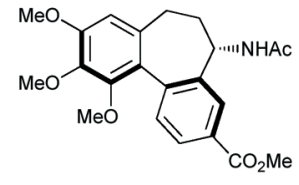

$(-)$-allocolchicine 2
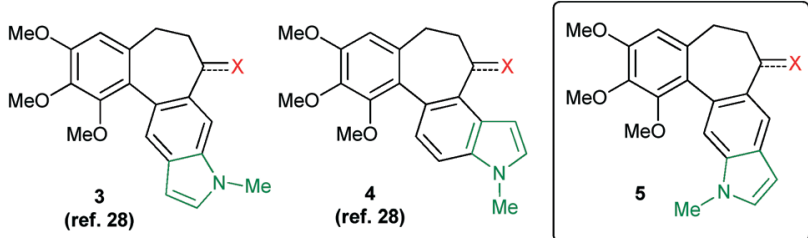

$\mathrm{X}=\mathrm{O}, \mathrm{OH}, \mathrm{NHAC}$

Fig. 1 Structures of colchicine (1), allocolchicine (2), known pyrroloallocolchicinoids (3 and 4 ) and their target constitutional isomers of type 5. 


\section{Results and discussion}

Synthesis

Multiple strategies to access the tricyclic fused ring system of allocolchicine (2) and its analogues have been developed to date. ${ }^{31-43}$ For the construction of the carbocyclic skeleton of 5, we followed the strategy depicted in Scheme 1, which relies on intramolecular Friedel-Crafts acylation and Pd-catalysed cross-coupling as the $\mathrm{C}-\mathrm{C}$ bond forming steps.

First, the halogen-selective Suzuki-Miyaura reaction between methyl (iodoaryl)propionate 7 (ref. 30) and indolylboronate 8 generated biaryl 9, which upon basic hydrolysis of the methyl ester yielded acid 6. Treatment of 6 with (1-chloro-2-methylpropenyl)dimethylamine (10, Ghosez reagent $)^{44,45}$ resulted in the formation of acyl chloride 11 which was used in situ in the intramolecular Friedel-Crafts

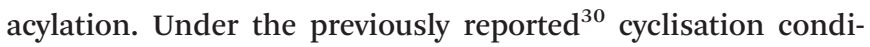
tions $\left(\mathrm{ZnCl}_{2}, 0.02 \mathrm{M} 11\right.$ in DCM), tetracycle 12 was formed as a single regioisomer, however, in only 17\% yield (as a consequence of the acid-catalysed oligomerisation of the starting material). Application of $\mathrm{Et}_{2} \mathrm{AlCl}$ or $\mathrm{EtAlCl}_{2}$ as protonscavenging Lewis acids ${ }^{46}$ also gave only low yields of 12 due to competing nucleophilic addition of the Al-alkyl reagent to acid chloride 11. However, treatment of $\mathbf{1 1}$ with an excess of bulky diisobutylaluminum chloride resulted in efficient seven-membered ring closure and, in addition, in situ reduction of the carbonyl group ${ }^{47,48}$ (via $\beta$-hydride transfer). This way, tetracyclic alcohol rac-13 was obtained in $68 \%$ yield over three steps in a one-pot procedure. $\ddagger$ After cyclization, the bromine in rac-13 was removed via halogen-lithium exchange/ protonation to give rac-5a in $96 \%$ yield (32\% overall from 7 ) (Scheme 2).

Alcohol rac-5a further served as the substrate for the synthesis of allocolchicinoids with various functionalities at $\mathrm{C}(7) \S$ (Scheme 3). Thus, oxidation of rac-5a with $\mathrm{N}$-methylmorpholine- $\mathrm{N}$-oxide in the presence of catalytic

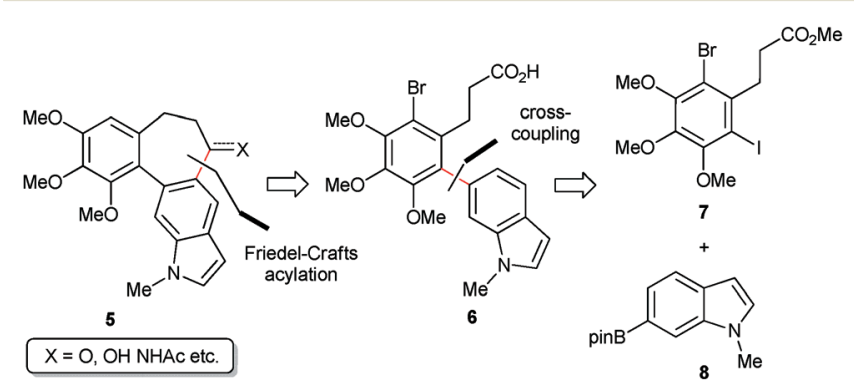

Scheme 1 Retrosynthetic analysis of pyrrolo-allocolchicinoids of type 5.

\$ To our best knowledge, this is the first example demonstrating the feasibility of the tandem Friedel-Crafts acylation-carbonyl group reduction using (i-Bu) $)_{2} \mathrm{AlCl}$ as an activator (Lewis acid) and an in situ reducing agent. $\S$ Colchicine numbering (Fig. 1) is used throughout the manuscript.

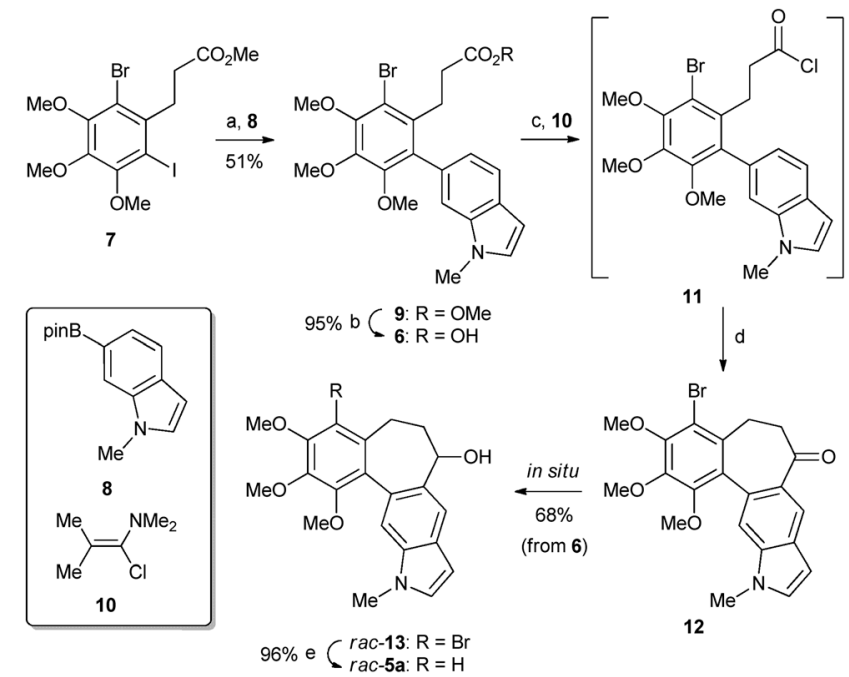

Scheme 2 Construction of the carbocyclic scaffold of the target allocolchicinoids. Reagents and conditions: (a) $\mathrm{Pd}(\mathrm{OAc})_{2}(0.05$ equiv.), $\mathrm{PPh}_{3}$ (0.1 equiv.), $\mathrm{Cs}_{2} \mathrm{CO}_{3}$, toluene, reflux, $24 \mathrm{~h}$; (b) LiOH aq., THF/ $\mathrm{MeOH}, 40{ }^{\circ} \mathrm{C}, 1 \mathrm{~h}$; (c) $\mathrm{CH}_{2} \mathrm{Cl}_{2}, 0{ }^{\circ} \mathrm{C}, 12 \mathrm{~h}$; (d) (i-Bu) ${ }_{2} \mathrm{AlCl}$ (2 equiv.), $\mathrm{CH}_{2} \mathrm{Cl}_{2}, 0{ }^{\circ} \mathrm{C}$ to r.t., $30 \mathrm{~min}$; (e) t-BuLi, THF, $-78{ }^{\circ} \mathrm{C}, 30 \mathrm{~min}$, then $\mathrm{MeOH}$.

$\mathrm{Pr}_{4} \mathrm{NRuO}_{4}$ (Ley oxidation) ${ }^{49}$ gave ketone $5 \mathrm{~b}$ in $90 \%$ yield. Quantitative conversion of rac-5a to the corresponding acetate $r a c-5 c$ was achieved via transesterification with ethyl acetate. The reaction of rac-5a with $\mathrm{Zn}\left(\mathrm{N}_{3}\right)_{2} \cdot 2$ Py under Mitsunobu conditions $^{50}$ resulted in the formation of azide rac-5d $(91 \%$ yield) which was subsequently reduced with lithium aluminum hydride to amine rac-5e (93\% yield). Finally, acylation of rac-5e with acetic anhydride in pyridine provided acetamide rac-5f in $94 \%$ yield.
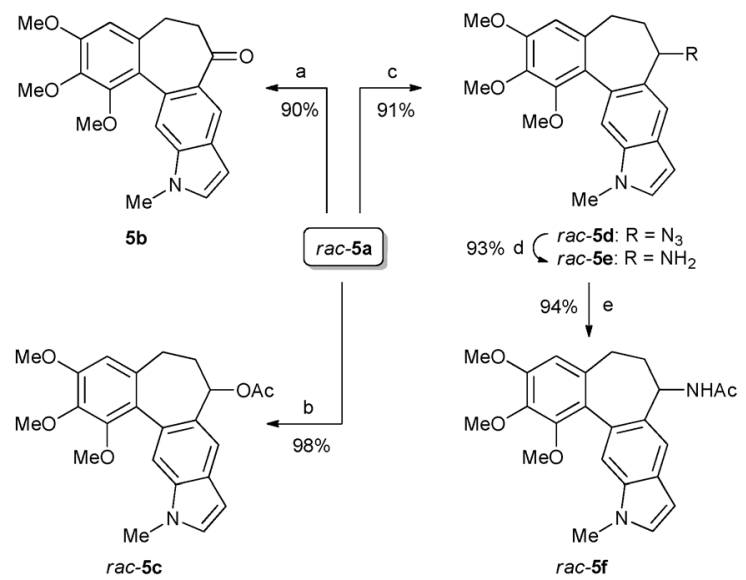

Scheme 3 Synthesis of pyrrolo-allocolchicinoids $\mathbf{5 a - f}$ with various functionalities at $\mathrm{C}(7)$. Reagents and conditions: (a) $\mathrm{N}$-methylmorpholine- $\mathrm{N}$-oxide, $\mathrm{Pr}_{4} \mathrm{NRuO}_{4}$ (0.05 equiv.), molecular sieves $4 \AA, \mathrm{CH}_{2} \mathrm{Cl}_{2} / \mathrm{MeCN}$, r.t., $1 \mathrm{~h}$; (b) EtOLi, EtOAc, $40{ }^{\circ} \mathrm{C}, 50$ torr, 30 min; (c) $\mathrm{Zn}\left(\mathrm{N}_{3}\right)_{2} \cdot 2 \mathrm{Py}, \mathrm{PPh}_{3}$, diisopropyl azodicarboxylate, toluene, r.t., 5 h; (d) $\mathrm{LiAlH}_{4}, \mathrm{THF}$, r.t., $24 \mathrm{~h}$; (e) $\mathrm{Ac}_{2} \mathrm{O}$, pyridine, $\mathrm{CH}_{2} \mathrm{Cl}_{2}, \mathrm{O}^{\circ} \mathrm{C}, 10 \mathrm{~min}$. 
Table 1 Anti-proliferative and apoptosis-inducing activity of pyrroloallocolchicinoids $5 a-f$ (in comparison with colchicine (1)) against BJAB Burkitt-type lymphoma cells

\begin{tabular}{lllll}
\hline & $\begin{array}{l}\mathrm{IC}_{50}{ }^{a} \\
{[\mu \mathrm{M}]}\end{array}$ & $\begin{array}{l}\mathrm{AC}_{50}{ }^{b} \\
{[\mu \mathrm{M}]}\end{array}$ & $\begin{array}{l}\text { Proliferation } \\
\text { inhibition at } \mathrm{AC}_{50}[\%]\end{array}$ & $\begin{array}{l}\text { Necrosis at } \\
\mathrm{AC}_{50}{ }^{c}[\%]\end{array}$ \\
\hline Colchicine (1) & 0.02 & 0.03 & n.d. & n.d. \\
$\mathbf{5 a}(\mathrm{X}=\mathrm{OH})^{d}$ & 0.001 & 0.001 & 52 & 7 \\
$\mathbf{5 b}(\mathrm{X}=\mathrm{O})$ & $0.01-0.05$ & 0.05 & 98 & 4 \\
$\mathbf{5 c}(\mathrm{X}=\mathrm{OAc})$ & $0.01-0.05$ & 0.05 & 89 & 0 \\
$\mathbf{5 d}\left(\mathrm{X}=\mathrm{N}_{3}\right)$ & 50 & $>100$ & 30 & 1 \\
$\mathbf{5 e}\left(\mathrm{X}=\mathrm{NH}_{2}\right)$ & $0.5-1$ & 5 & 90 & 29 \\
$\mathbf{5 f}(\mathrm{X}=\mathrm{NHAc})$ & $>100$ & $>100$ & - & -
\end{tabular}

Each experiment was performed in triplicate; n.d. $=$ not determined. ${ }^{a} \mathrm{IC}_{50}$ : concentration of the compound causing $50 \%$ cell growth inhibition after $24 \mathrm{~h}$, as determined by CASY cell counting. ${ }^{b} \mathrm{AC}_{50}$ : concentration of the compound causing $50 \%$ cell apoptosis after $72 \mathrm{~h}$, as determined by a DNA fragmentation assay. ${ }^{c}$ Necrosis level caused by the compound at $\mathrm{AC}_{50}$ concentration after $1 \mathrm{~h}$, measured by the LDH release assay. ${ }^{d} \mathrm{X}$ corresponds to the functional group at $\mathrm{C}(7)$ (Fig. 1).

\section{Biological assessment}

The cytostatic activity of the target pyrrolo-allocolchicinoids 5a-f against BJAB (Burkitt-type lymphoma) cells was evaluated using colchicine (1) as a standard (Table 1). All compounds exhibited a clear dose-dependent effect on cell proliferation and apoptosis (see the ESI $\dagger$ for detailed information). As a general tendency, compounds bearing an oxygen-based functionality at $\mathrm{C}(7)$ possessed higher cytostatic activity and lower unspecific cytotoxicity compared to the corresponding analogues with a $\mathrm{C}(7)-\mathrm{N}$ bond. Acetate $r a c-5 c$ was identified as a particularly potent antimitotic agent, as it caused virtually complete inhibition of cell proliferation at low nanomolar concentrations (Fig. 2), while no necrosis was detected (in a lactate dehydrogenase $(\mathrm{LDH})$ release assay after $1 \mathrm{~h}$ ) at concentrations of up to $5 \mu \mathrm{M}$. It is noteworthy that the novel pyrroloallocolchicinoids $\mathbf{5 a - f}$ possess biological activity in the same concentration range as the previously reported isomeric series 3 and 4 (Fig. 1). This indicates that the mode

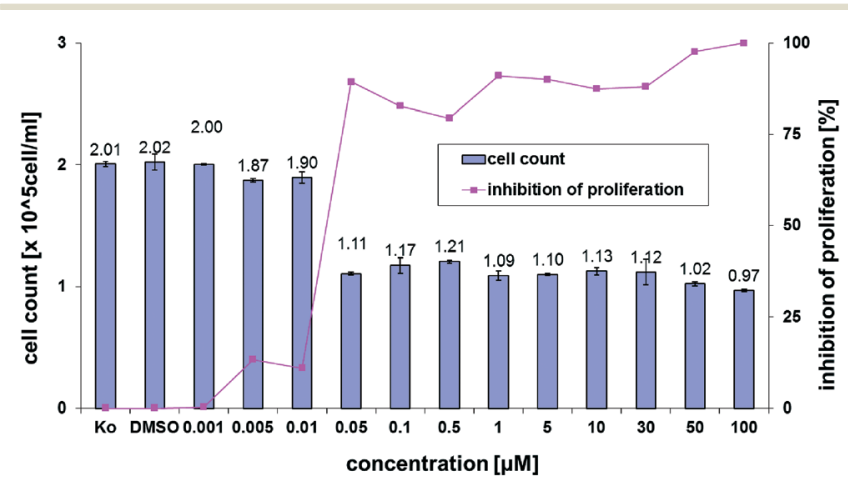

Fig. 2 Concentration-dependent inhibition of BJAB lymphoma cell proliferation by $5 c$ as determined by CASY cell counting after $24 \mathrm{~h}$. of pyrrole ring fusion to the allocolchicine scaffold does not induce a profound influence on the cytostatic properties.

To probe whether the cytostatic activity of the pyrroloallocolchicinoids might be a consequence of tubulin binding, acetate $r a c-5 c$ as well as $r a c-3(\mathrm{X}=\mathrm{OH})$ and $r a c-4(\mathrm{X}=\mathrm{OH})($ as the most active of the previously reported compounds) were tested in a fluorescence-based tubulin polymerisation assay (Fig. 3). The depicted turbidimetry curves reflect the effect of all three compounds on the microtubule assembly from purified tubulin. A clear inhibition was noted, as the rate of assembly and the final amount of microtubules were clearly lower in the presence of allocolchicinoids than those in the control experiment. The extent of inhibition increased steadily with the molar ratio of the total ligand to the total tubulin in the solution $(R)$. All three compounds demonstrated a sub-stoichiometric mode of action. ${ }^{51}$ Half-inhibition of tubulin polymerisation was achieved at a molar ratio (compound/tubulin) of 0.125 for rac-5c, 0.264 for $\operatorname{rac}^{-3}(\mathrm{X}=\mathrm{OH})$ and 0.228 for rac-4 $(\mathrm{X}=\mathrm{OH})$ (the corresponding value for colchicine (1) is $0.375,{ }^{52}$ and that for combretastatin A-4 is 0.09 (own data)). Thus, the high cytostatic activity of pyrroloallocolchicinoids 3-5 appears to be a direct consequence of efficient tubulin binding.
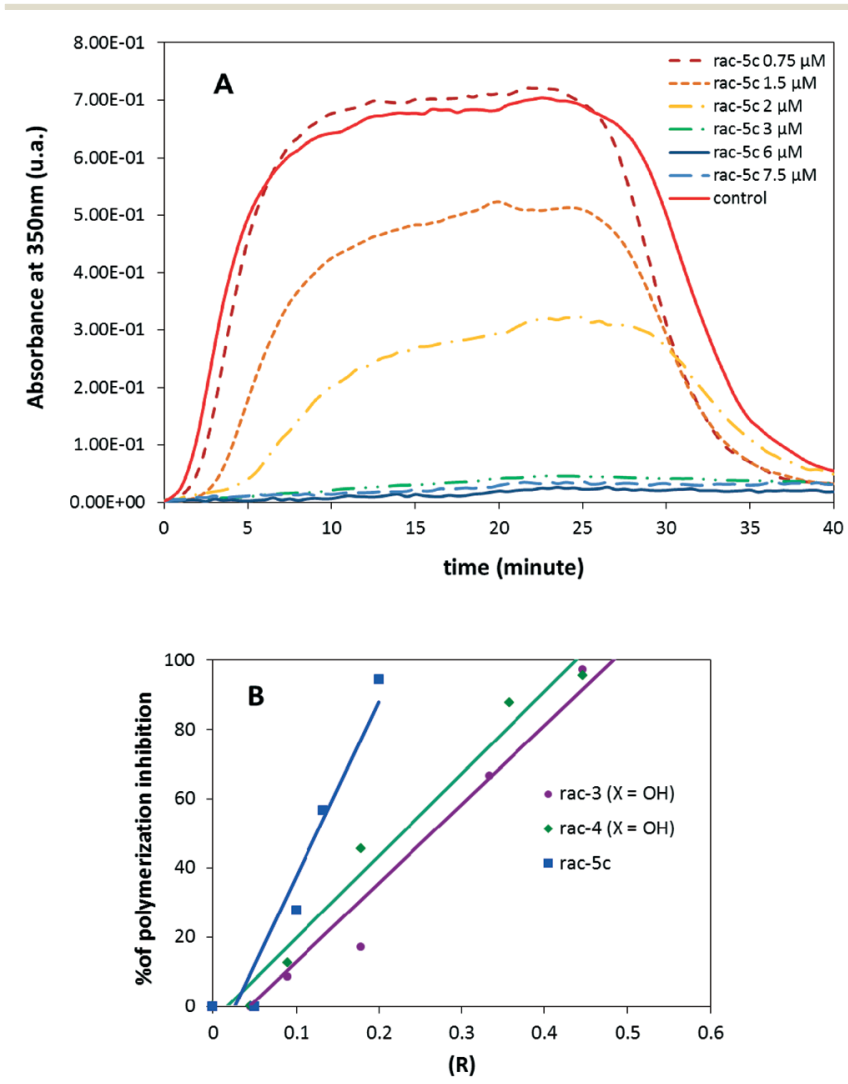

Fig. 3 Effect of pyrrolo-allocolchicinoids rac-5c, rac-3 $(\mathrm{X}=\mathrm{OH})$ and rac-4 $(\mathrm{X}=\mathrm{OH})$ on the polymerisation of tubulin. A: Turbidimetry curves of tubulin assembly in the presence of different concentrations of rac5c. B: Comparative polymerisation inhibition efficiency of rac-5c and previously reported allocolchicinoids rac-3 $(\mathrm{X}=\mathrm{OH})$ and rac-4 $(\mathrm{X}=$ $\mathrm{OH}) ; R$ = ligand-to-tubulin molar ratio. 


\section{Conclusions}

A synthetic route to a new structural type of pyrroloallocolchicinoids was developed. The cytostatic properties of target compounds 5a-f bearing different functional groups were evaluated employing Burkitt-like lymphoma cells (BJAB). Allocolchicinoids 5a-c exhibited potent anti-proliferative and apoptosis-inducing activity with $\mathrm{IC}_{50}$ and $\mathrm{AC}_{50}$ values in the low nanomolar concentration range along with low unspecific cytotoxicity (according to LDH release measurements). The in vitro tubulin polymerisation assay revealed that compound $5 \mathbf{a}$ as well as the previously reported structural isomers rac-3 $(\mathrm{X}=\mathrm{OH})$ and rac-4 $(\mathrm{X}=\mathrm{OH})$ inhibit the assembly of tubulin into microtubules. This indicates that, similarly to colchicine, the anti-proliferative and proapoptotic effects of pyrrolo-allocolchicinoids most probably result from the disruption of the mitotic spindle formation and subsequent cell cycle arrest.

\section{Acknowledgements}

We gratefully acknowledge the Russian Foundation for Basic Research (project 14-03-91342), the Deutsche Forschungsgemeinschaft (project 857/18-1) and the Ministry of Education and Science of the Russian Federation (project 4.619.2014/K) for financial support. N. S. thanks the Alexander von Humboldt Foundation for a postdoctoral fellowship. A. Prokop gratefully acknowledges support from Dr. KleistStiftung, Berlin.

\section{Notes and references}

1 H.-G. Capraro and A. Brossi, in The Alkaloids: Chemistry and Pharmacology, ed. A. Brossi, Academic Press, Orlando, 1984, vol. 23, p. 1.

2 C. Le Hello, in The Alkaloids: Chemistry and Biology, ed. G. A. Cordell, Academic Press, San Diego, CA, 1999, vol. 53, p. 287.

3 B. Bhattacharyya, D. Panda, S. Gupta and M. Banerjee, Med. Res. Rev., 2008, 28, 155.

4 B. Gigant, A. Cormier, A. Dorleans, R. B. G. Ravelli and M. Knossow, in Topics in Current Chemistry, ed. T. Carlomagno, Springer-Verlag, Berlin, 2009, vol. 286, p. 259.

5 S. Sapra, Y. Bhalla, Nandani, S. Sharma, G. Singh, K. Nepali, A. Budhiraja and K. L. Dhar, Med. Chem. Res., 2013, 22, 531.

6 For general reviews on tubulin as a target in anticancer therapy, see: E. Stec-Martyna, M. Ponassi, M. Miele, S. Parodi, L. Felli and C. Rosano, Curr. Cancer Drug Targets, 2012, 12, 658; C. D. Katsetos and P. Dráber, Curr. Pharm. Des., 2012, 18, 2778.

7 For general reviews on microtubule-binding agents, see: C. Dumontet and M. A. Jordan, Nat. Rev. Drug Discovery, 2010, 9, 790; R. A. Stanton, K. M. Gernert, J. H. Nettles and R. Aneja, Med. Res. Rev., 2011, 31, 443.

8 T. Graening and H.-G. Schmalz, Angew. Chem., Int. Ed., 2004, 43, 3230.

9 J. Chen, T. Liu, X. W. Dong and Y. Z. Hu, Mini-Rev. Med. Chem., 2009, 9, 1174.
10 Y. Lu, J. J. Chen, M. Xiao, W. Li and D. D. Miller, Pharm. Res., 2012, 29, 2943.

11 G. Sivakumar, Curr. Med. Chem., 2013, 20, 892.

12 C. Putterman, E. Benchetrit, Y. Caraco and M. Levy, Semin. Arthritis Rheum., 1991, 21, 143.

13 Y. Finkelstein, S. E. Aks, J. R. Hutson, D. N. Juurlink, P. Nguyen, G. Dubnov-Raz, U. Pollak, G. Koren and Y. Bentur, Clin. Toxicol., 2010, 48, 407.

14 M. Marrelli, F. Conforti, G. A. Statti, X. Cachet, S. Michel, F. Tillequin and F. Menichini, Curr. Med. Chem., 2011, 18, 3035.

15 Y. Shan, J. Zhang, Z. Liu, M. Wang and Y. Dong, Curr. Med. Chem., 2011, 18, 523.

16 H. Rajak, P. K. Dewangan, V. Patel, D. K. Jain, A. Singh, R. Veerasamy, P. C. Sharma and A. Dixit, Curr. Pharm. Des., 2013, 19, 1923.

17 A. Brancale and R. Silvestri, Med. Res. Rev., 2007, 27, 209.

18 S. Combes, P. Barbier, S. Douillard, A. McLeer-Florin, V. Bourgarel-Rey, J.-T. Pierson, A. Yu. Fedorov, J.-P. Finet, J. Boutonnat and V. Peyrot, J. Med. Chem., 2011, 54, 3153; O. G. Ganina, E. Daras, V. Bourgarel-Rey, V. Peyrot, A. N. Andresyuk, J.-P. Finet, A. Yu. Fedorov, I. P. Beletskaya and S. Combes, Bioorg. Med. Chem., 2008, 16, 8806.

19 O. Boyé and A. Brossi, in The Alkaloids: Chemistry and Pharmacology, ed. A. Brossi and G. A. Cordell, Academic Press, San Diego, CA, 1992, vol. 41, p. 125.

20 R. Brecht, G. Seitz, D. Guenard and S. Thoret, Bioorg. Med. Chem., 2000, 8, 557.

21 F. Buttner, S. Bergemann, D. Guenard, R. Gust, G. Seitz and S. Thoret, Bioorg. Med. Chem., 2005, 13, 3497.

22 A. Joncour, A. Decor, J.-M. Liu, M.-E. T. H. Dau and O. Baudoin, Chem. - Eur. J., 2007, 13, 5450.

23 N. Nicolaus, J. Zapke, P. Riesterer, J.-M. Neudoerfl, A. Prokop, H. Oschkinat and H.-G. Schmalz, ChemMedChem, 2010, 5, 661.

24 F.-D. Boyer, J. Dubois, S. Thoret, M.-E. T. H. Dau and I. Hanna, Bioorg. Chem., 2010, 38, 149.

25 N. Jain, D. Yada, T. B. Shaik, G. Vasantha, P. S. Reddy, S. V. Kalivendi and B. Sreedhar, ChemMedChem, 2011, 6, 859.

26 N. Nicolaus, J. Reball, N. Sitnikov, J. Velder, A. Termath, A. Y. Fedorov and H.-G. Schmalz, Heterocycles, 2011, 82, 1585.

27 E. Chosson, F. Santoro, C. Rochais, J. Sopkova-de Oliveira Santos, R. Legay, S. Thoret, T. Cresteil, M. S. Sinicropi, T. Besson and P. Dallemagne, Bioorg. Med. Chem., 2012, 20, 2614.

28 N. Sitnikov, J. Velder, L. Abodo, N. Cuvelier, J.-M. Neudorfl, A. Prokop, G. Krause, A. Y. Fedorov and H.-G. Schmalz, Chem. - Eur. J., 2012, 18, 12096.

29 N. S. Sitnikov, A. S. Kokisheva, G. K. Fukin, J.-M. Neudörfl, H. Sutorius, A. Prokop, V. V. Fokin, H.-G. Schmalz and A. Yu. Fedorov, Eur. J. Org. Chem., 2014, 29, 6481.

30 Y. V. Voitovich, E. S. Shegravina, N. S. Sitnikov, V. Faerman, V. V. Fokin, H.-G. Schmalz, S. Combes, D. Allegro, P. Barbier, I. P. Beletskaya, E. V. Svirshchevskaya and A. Y. Fedorov, J. Med. Chem., 2015, 58, 692. 
31 For a review, see: N. S. Sitnikov and A. Y. Fedorov, Russ. Chem. Rev., 2013, 82, 393.

32 J. S. Sawyer and T. L. Macdonald, Tetrahedron Lett., 1988, 29, 4839.

33 A. V. Vorogushin, A. V. Predeus, W. D. Wulff and H.-J. Hansen, J. Org. Chem., 2003, 68, 5826.

34 M. Leblanc and K. Fagnou, Org. Lett., 2005, 7, 2849.

35 W. M. Seganish and P. DeShong, Org. Lett., 2006, 8, 3951.

36 G. Besong, K. Jarowicki, P. J. Kocienski, E. Sliwinski and F. T. Boyle, Org. Biomol. Chem., 2006, 4, 2193.

37 S. Djurdjevic and J. R. Green, Org. Lett., 2007, 9, 5505.

38 S. D. Broady, M. D. Golden, J. Leonard, J. C. Muir and M. Maudet, Tetrahedron Lett., 2007, 48, 4627.

39 G. Besong, D. Billen, I. Dager, P. Kocienski, E. Sliwinski, L. R. Tai and F. T. Boyle, Tetrahedron, 2008, 64, 4700.

40 F.-D. Boyer and I. Hanna, Eur. J. Org. Chem., 2008, 4938.

41 N. Nicolaus, S. Strauss, J.-M. Neudoerfl, A. Prokop and H.-G. Schmalz, Org. Lett., 2009, 11, 341.
42 N. Nicolaus and H.-G. Schmalz, Synlett, 2010, 2071.

43 S. Djurdjevic, F. Yang and J. R. Green, J. Org. Chem., 2010, 75, 8241.

44 A. Devos, J. Remion, A. M. Frisque-Hesbain, A. Colens and L. Ghosez, J. Chem. Soc., Chem. Commun., 1979, 1180.

45 B. Haveaux, A. Dekoker, M. Rens, A. R. Sidani, J. Toye and L. Ghosez, Org. Synth., 1979, 59, 26.

46 T. Okauchi, M. Itonaga, T. Minami, T. Owa, K. Kitoh and H. Yoshino, Org. Lett., 2000, 2, 1485.

47 G. Giacomelli and L. Lardicci, J. Org. Chem., 1981, 46, 3116.

48 J. S. Cha, O. O. Kwon, S. Y. Kwon, J. M. Kim, W. W. Seo and S. W. Chang, Synlett, 1995, 1055.

49 S. V. Ley, J. Norman, W. P. Griffith and S. P. Marsden, Synthesis, 1994, 639.

50 M. C. Viaud and P. Rollin, Synthesis, 1990, 130.

51 B. Perez-Ramirez, J. M. Andreu, M. J. Gorbunoff and S. N. Timasheff, Biochemistry, 1996, 35, 3277.

52 H. Sternlicht and I. Ringel, J. Biol. Chem., 1979, 254, 10540. 